\title{
Occupation ICSR Terminology
}

National Cancer Institute

\section{Source}

National Cancer Institute. Occupation ICSR Terminology. NCI Thesaurus. Code C54585.

Terminology used in Individual Case Safety Reports to specify information on an occupation of reporter, section E3 of FDA MedWatch Form. 